SISTEMA
ELETRÔNICO
DE REVISTAS
SER I UFPR

\title{
An Integrated Perspective of Indigenous Territories in Ten Canoes
}

\section{Uma perspectiva integrada dos territórios indígenas no filme "Ten Canoes" [Dez Canoas]}

\author{
Aline FREY ${ }^{1 *}$ \\ ${ }^{1}$ University of Queensland, Australia \\ *E-mail of contact: alinefrey09@gmail.com
}

Article received on November 13, 2018, final version accepted on May 20, 2019.

\begin{abstract}
Indigenous knowledge can challenge liberal and anthropocentric definitions of water as human property. In this article, I examine the close relationship of Indigenous people with their waterscapes as portrayed in the
\end{abstract} Australian feature film Ten Canoes.

Keywords: cinema; Australia; environment.

RESUMO: O conhecimento indígena pode desafiar as definições liberais e antropocêntricas da água como propriedade humana. Neste artigo, examino a estreita relação dos povos indígenas com suas paisagens aquáticas como retratada no filme australiano "Ten Canoes" [Dez Canoas].

Palavras-chave: cinema; Austrália; Meio-Ambiente.

\section{Introduction}

Drawing on Indigenous knowledge research and decolonising theories, I explore differences between Indigenous and Western perspectives on the theme of water preservation, as well as their consequences for the local and global environment.
My primary objective in this article is to examine the relationship between Indigenous people and waterscapes in the Australian feature film Ten Canoes (2006) (directed by Rolf de Heer and Peter Djiggir).

Ten Canoes is a film set in Australia, a "highly water-scarce continent" with extremely variable and unpredictable rainfall, which has led to diverse weather conditions and unstable surface water 
availability (Burdon et al., 2015). Before European arrival, these local diversities were respected, as Indigenous social and economic ways of life were adapted to natural resource systems. While the U.N. Declaration of Universal Human Rights regards water as essential for human survival, Indigenous populations continue to struggle to access and protect their water resources. Climate change has increased these struggles by, for example, reducing water accessibility (Altman \& Jackson, 2008). In this sense, Indigenous people knowledge can play a fundamental role in the process of raising awareness of the necessity of sustainable uses of natural resources.

Ten Canoes portrays the connection between the Yolngu people and the centrality of their homeland to their culture, history and cosmology. Yolngu means "Aboriginal person" and refers generically to the inhabitants of north-eastern areas of Arnhem Land. As Yolngu is a generic label, there are specific names to acknowledge different clans, such as Manggalili and Djapu. The challenge in the use of any generic name is that it can homogenise a diverse group of people. For Morphy (1991, p. 40), a more accurate definition of Yolngu is as "a form of social organization, a culture area, a linguistic entity, or a social universe rather than to a named group of people". The Arafura swamp is a large and diverse inland freshwater basin belonging to and managed by Yolngu people. They are renowned for expertly deriving part of their subsistence from land and natural resources while, at the same time, preserving the ecosystem of the region (White, 2003 , p. 187). However, climate change global threats such as the rise of sea levels, the spread of non-endemic organisms and the introduction of grass-fed cattle present a contemporary challenge to the Yolngu people's practices of land and water care. Aboriginal ranger groups in the area were hit first, but the consequences are broader for the community and their longstanding natural and cultural resource management (Weston et al., 2012; Gorman et al., 2007).

\section{Aboriginal people and Australian water resources}

To enhance my study of the Yolngu people's relationship with their environment in Ten Canoes, I rely on Deborah Bird Rose's extensive anthropological research on Aboriginal Australians and hegemonic western perspectives. For the purposes of this article, I engage with Rose's analysis of Australian Aboriginal notions of human and animal connectivity in relation to the work of Australian eco-feminist Val Plumwood on "Philosophical Animism". Plumwood criticises the "hyper-separation" of Western philosophy that results in simplistic dichotomies, such as "nature/culture, female/male, matter/mind, savage/civilised" (Rose, 2013, p. 94). In this sense, the ideology that underpins nature's inferiority also subjugates disadvantaged social groups, particularly women and Indigenous people, thereby inevitably entangling social with ecological justice. Plumwood adds that this hyper-separation further favours a subordination of one term by the other: the dichotomies render inferior all terms related to nature. In response to this hyper-separated worldview, Val Plumwood defends "interspecies communication" as key to the recognition and engagement with "earth others" (Plumwood, 2002, p. 176).

Rose takes up Plumwood to support her analysis of the Elder Aboriginal Steve Meredith's discourse on the impossibility of hyper-separation between humans and nature. Meredith (as cited by Rose) argues that studying animals apart from 
humans is an impossible task, even at highly specialised university studies. To understand birds, for example, it is necessary to study the plants they eat. Of course, these are connected to the soil and water, while both are related to human activities. Meredith also argues that while one might feel superior for going to university to do research, another activity might be underway simultaneously, i.e., once researchers go to sleep (or once they die?), the ants studied might carry out research on humans. Rose (2013, p. 99) concludes that this animist perspective is based on the connectivity between all animal life and earth beings and "tells us that humans are not only acting upon the world, but that others are also taking notice and acting upon humans". Rose's studies re-examine the environmental consequences of a sentient world in which mindfulness is not restricted to humans.

The term 'animism' is not of Indigenous origin. It is a 19th century colonial construct developed by E. B. Tylor (1958) to convey the Indigenous principle that non-humans have souls/spirits. Current "new animism" studies focus on the social relationship between humans and non-humans, pointing to the relational ontology of animism (Harvey, 2005). For example, Tim Ingold (2006, p. 14) argues that Western dichotomies are historically contingent and only one of many possibilities of interpreting human and non-human relationship. He adds that although traditional Western thoughts tend to undermine human-environment connections, humans perceive their environment primarily because they are situated in it, within a "domain of entanglement". In this sense, he concludes that Indigenous animism can work as a generalization not based on a way of knowing but rather as a way of being in a world of continuous flux.

A consequence of this paradigm shift is the proposition that all living beings, including rivers and swamps, are not exclusively human domains but have rights of existence and perpetuation. Altman \& Jackson (2008) argue that Indigenous sustainability in Australia is demonstrable in the remarkably preserved and biodiverse areas managed by them, containing the most undamaged forests, streams and reefs of the country. The history of Indigenous management is often linked to a key term: TEK (traditional ecological knowledge), which Hunn (1993) describes as: 1. 'Traditional' meaning that it has been tested and transmitted through Indigenous generations; 2. 'Ecological' emphasizes Indigenous interaction with the environment; and 3. 'Knowledge' that could be taken with them, i.e., even when they were hunter-gathers, knowledge served as a portable technology, thereby breaking the colonial link between the lack of tools/technology and primitivism. Berkes (1993, p. 3) defines TEK as "a cumulative body of knowledge and beliefs, handed down through generations by cultural transmission" regarding the connection between all living beings with each other and their own environment. Thus, TEK is a collective knowledge based on long-term mutual observation, understanding and interaction with a specific territory.

Studies with Aboriginal groups demonstrate that flexibility is key for their water resource management. In contrast to constructing dams, for example, Indigenous flexibility guaranteed their stocks of water supplies. 'Indigenous people's main adaptation to uncertainty was to develop social ties that enabled people to move to resources as they became available" (Rose, 2005, p. 41). Another water resource strategy was centred on rainmaking rituals. This low-scale intervention is not intended to completely transform the landscape or the water supply but to improve water resources at a specific space/time thereby nourishing life (Rose, 2005, p. 45). This practice is occasional and limited, 
not affecting a river's course or flow. It radically contrasts to the enterprises of dams and mining that Indigenous people have historically fought to preserve and nourish life on their own territories.

Before examining Ten Canoes, it is important to recall the modern history of Yolngu people and its chronology of battles. In the early 1960s, the federal government leased the Gove Peninsula for bauxite mining (Eggerking, 2014). In 1963, the Yolngu people responded by sending a petition presented as a pair of bark paintings to the government in Canberra. Three years later, a Swiss and Australian mining conglomerate resumed extraction activity through Nabalco, the North Australian Bauxite and Alumina Company. In 1968, the Yolngu went to court against the Commonwealth and Nabalco. This was the first case of Indigenous land rights in Australia. ${ }^{1}$ The Gove land-rights case took three years (1969-1971) and failed to acknowledge Indigenous rights. However, it galvanised a growing movement for Aboriginal land rights paving the way for the Aboriginal Land Rights Act 1976 (Northern Territory). The next protracted legal battle for the Yolngu related to their Native Title claim and was mounted in the aftermath of the landmark Mabo case in 1992, which overturned the doctrine of terra nullius and ultimately resulted in the recognition of Indigenous Native Title as a form of land right.

All these legal processes included studies of Indigenous connectivity to water resources, such as "rivers, water holes, springs, saltwater, floods" as well as different states of water transformations, as clouds and smoke when in contact with fire; it included studies of human activities such as "hunting, fishing, food preparation and ceremonial activities such as rainmaking" (Toussaint et al., 2005, p. 62). Taken together, the studies provided evidence of
Indigenous people's connection to their traditional territories based on their use of and relation to water resources. However, while Indigenous people now have legal ownership of $20 \%$ of Australian lands, their rights to recognised bodies of water are estimated at less than $0.01 \%$ of the country's water resources (Jackson \& Barber, 2013). In Australian law, there is a distinction between land and water rights.

This contradicts Indigenous understanding of "water and land as an interrelated and indissoluble whole-country" (Jackson \& Barber, 2013). As expressed by Neale and Turner (2015), "a claim to water is not simply a claim to a resource. It is a claim to knowledge and to the constitution of place". In this sense, the separation between land and water rights violates the Indigenous integrated perspective of their territory as integrally connected and part of the "cultural landscape", rather than divided into isolated resources (Jackson \& Barber, 2013). Aboriginal people's connection to bodies of water is "construed spiritually, socially and jurally, according to the same fundamental principles as affiliations to terrestrial places in the land" (Langton, 2006, p. 144). The Indigenous relationship with the ancient past and its connection with the present are therefore necessarily derived from divine beings that live in specific places, such as land, water and sky.

This standpoint is illustrated in Ten Canoes, wherein the swamp is a key element of the cultural landscape and waterscape for the Yolngu people's cosmology as well as their social and economic life. According to Ginytjirrang Mala (1994, p. 5): “in the Yolngu world view, water is the giver of sacred knowledge, all ceremonies and lands. Whether it's fresh or salt, travelling on or under the land, or in the sea, water is the source of all that is holy".

\footnotetext{
${ }^{1}$ Milirrpum v Nabalco Pty Ltd and the Commonwealth of Australia (Eggerking, 2014).
} 
The life-sustaining connection between water and the community is portrayed in Ten Canoes as the swamp, which is defined as synonymous with life. The film was a successful collaborative project between Indigenous and non-Indigenous people. It earned the distinction of being the first Australian fictional film set entirely in the pre-colonial period. It is also the first Australian film fully spoken in Aboriginal language, predominantly Ganalbingu (Walker, 2015). Contrary to fears that the need for subtitling would hurt international circulation, the film met with a widespread, distinguished global reception; it received the Special Jury Prize in the Un Certain Regard category at the Cannes International Film Festival in 2006 and six awards, including best film and cinematography at the 48th annual AFI (Australian Film Institute). Sponsored by the Australian Film Finance Corporation, the Adelaide Film Festival and others, the film was directed by Rolf de Heer and Peter Djiggir together with the Yolngu people of the Ramingining community. ${ }^{2}$

\section{Life is the Swamp: Indigenous cosmologies in Ten Canoes.}

Film director de Heer was originally invited by one of the most famous of Aboriginal actors, David Gulpilil [Ridjimiraril Dalaithngu], to develop a film with his Yolngu community of Ramingining. In one of the director's visits to the Ramingining community, Gulpilil suggested that they needed ten canoes (Palace Films, 2006). De Heer did not understand the idea until seeing one of anthropologist
Donald Thomson 1930's photos taken in Arnhem Land (Davis 2007, p. 14). The photo of ten canoeists was one among the vast collection of Thomson's material that gave a glimpse of life in the Arafura swamp. Both the director and actor imagined that a narrative would unfold from that photo. ${ }^{3}$

To make Ten Canoes, de Heer relied on Thomson's anthropological photographs as well as on the community's oral histories. The film brought the acknowledgment of Indigenous property rights to a new level as "the Ten Canoes Agreement recognises the Ramingining community's property rights for all artefacts and sets made for and used in this film" (Davis 2007, p. 6-7). The film was a collaborative project between de Heer and the Yolngu people, especially co-director Peter Djiggir and the actor David Gulpilil. The close relationship between de Heer and Gulpilil had begun years before on the set of the feature film The Tracker (2002), with the actor playing the leading role. However, Gulpilil's career started many years before with Walkabout (1971) (directed by Nicholas Roeg), a remarkable achievement in Gulpilil's life, as well as landmark in the history of Australian and World cinema. In the credits, the characters are presented without their proper names but simply as "Girl" (Jenny Agutter), "White Boy" (Lucien John) and "Black Boy" (David Gulpilil). The plot revolves around the journey of two white schoolchildren abandoned by their father (John Meillon) who committed suicide in the water-starved Australian outback.

As the older sister and younger brother struggle to survive the isolated, deserted land, they meet an Aboriginal boy. Their attempts to communicate

\footnotetext{
2 Nowadays, a number of 800 Yolngu people live in Ramingining. The town created in the 1970s gathered around fifteen clans that speak about 8 different languages (Palace Films 2006).

${ }^{3}$ Donald Thomson worked extensively with the Yolngu community. He did not only take pictures he was involved with the Yolngu in resolving the Caledon Bay crisis in 1932-3 and his ashes were scattered on Yolngu country (Lambert-Pennington, 2001). Gulpilil possibly remembered the photo because of Thomson's longstanding association with Yolngu community until his death in 1970.
} 
initially fail. While the "Girl" is unable to achieve meaningful communication, it is the "White Boy" mimicking the sounds and gestures of someone drinking water who communicates with the Aboriginal boy. The latter promptly digs a hole with a wooden stick that functions as a straw, permitting them to drink the needed water. At the film's conclusion, the girl recalls the moment in which she swam naked along with her brother and the "Black Boy" in a paradisiacal spring.

The film portrays Australia in dichotomous terms: beautiful/dangerous, paradise/hell and welcoming/threatening, all juxtaposed along a timeline demarcating pre- and post-colonisation of Australia. The colonisers, the children, have the chance to learn alongside Aboriginal people to reconcile with nature, to free themselves from prejudices and to eschew their Western cultural and moral habits as they did when they shed their clothing for the swim. When the children reject this opportunity, the film suggests that its representation of the supposed Edenic relationship between the white girl and the Aboriginal boy is presented in order to demonstrate ultimately its utter implausibility.

After the white girl refuses the Aboriginal boy's marriage proposal, he commits suicide, forever locking him into the past and her into regret. In Wakulenko's (2000, p. 1306) analysis, the theme of Romanticism was evident in European arts during the English colonisation of Australia. Wakulenko views the film's white children abandoned in the desert by their father as a reference to the prisoners that the English Crown deported to the distant Australian colony, i.e., strangers abandoned in Aboriginal lands. The suicide committed by both the English father and the Aboriginal boy can be interpreted as an allegory of the future path of the two white youths; subsequently, they became English Australians, able to re-create their civilisation and to leave behind the Aboriginal lessons as a distant memory.

Walkabout features David Gulpilil, at age 15, as a non-English speaking Aboriginal boy. He is portrayed as a noble savage who guides the two lost children back to civilization. As films can be analysed based on their explicit intertextual conversations, when compared with and in dialogue with other films that the same actor has been in: the suicide scene of the Black boy is revisited in Gulpilil's later film, The Tracker. These two films are united thematically, as one inverts the outcome of the other. In both, Gulpilil assumes the role of a leader/tracker introducing 'the Other' to the Australian land, not as an exotic place but as his country. The Tracker is set in the early 1920 s, somewhere in the dry outback. As in Walkabout, water is absent. This emphasises the dry red landscape while addressing the dependence of the troopers on the tracker. Survival depends on his tracking skills and knowledge of the country, including making water accessible in an arid landscape because he knows where to find it.

In The Tracker, an Aboriginal tracker (David Gulpilil) is working for white colonial police officers while they are searching for an Aboriginal man, who has been accused of killing a white woman. Crossing an unfamiliar arid desert landscape, the police officers are forced to rely on the Aboriginal tracker to accomplish their mission. Collins and Davis in their book Australia Cinema After Mabo (2004, p. 14), analyse this film as depicting "Australian landscape as a mythic space" where the characters are presented as "archetypal figures". As in Walkabout, the credits present characters without proper names but simply as the Fanatic (Gary Sweet), the Follower (David Gameau) and the Tracker (David Gulpilil). The unjust and aggressive behaviour of the Fanatic against Aboriginal 
communities encountered by chance turns even the Follower against his commander. Collins \& Davis (2004) suggest that the film encourages the audience to want the killing of the white commander by the black Tracker.

The conflict between these two men culminates in the hanging of the Fanatic by the Tracker. When the Tracker refers visually to a rope in a tree, the viewer may recall the Aboriginal suicide portrayed by the same actor decades earlier; however, that intertextual reference to Walkabout (1971) is rapidly dispelled, as he does not turn against himself but against the white colonial man, the Fanatic. The film's dichotomy between good and evil people helps to define the ensuing events. There is no complexity in the character of the white colonial, Fanatic. He is unethical, a murderer, a racist and deserves to die in a summary way, like the way he has killed others. The Tracker hangs the Fanatic. The hanging is presented as a symbolic act of justice achieved. In this sense, the Tracker is a film that enables the young Aboriginal boy to avenge his own suicide, as now he is the one who will survive the colonial encounter.

It is again, as a guide, that David Gulpilil introduces the audience to his own country in Ten Canoes. Again, he tracks his familiar landscape, to invite an understanding of his people. However, this time, he is visually absent from the screen, and only recognisable by his already distinctly famous voice in the voice-over narration. This omniscient narrator is in a very different position from historical ethnographic documentaries where outsiders analyse Indigenous people. Gulpilil and de Heer seem to be playing with this documentary convention to create a powerful effect of recognition. The film was released with three versions, the theatrical commercial format in which he is speaking in English and two DVD versions in which he speaks Mandalpingu with and without English subtitles (Palace Films,
2006). In all of them, as the storyteller, he assumes the role of the mediator and translator, someone able to understand both cultures.

In Ten Canoes, David Gulpilil demonstrates that his character could survive the colonial contact, and that he now delights in presenting his own culture and cosmology. Ten Canoes is positioned as an ancestral story, as a lesson of sorts similar to Walkabout. The places and peoples are explicitly framed and emphasised as part of a storytelling. It is a telling that draws attention to itself, foregrounding its artifice. This narrative option underlines the importance of the story to continue to be called upon in the past and in the present to orient oneself in the world. It is not a realistic portrayal but a narrative about the importance of the Law and the cultural maintenance.

While the narrator begins his story with the English expression - Once upon a time - he signals that this is not an English story. Rather it is about a time long before English stories. In this subtle way, he reminds audiences that his story is surely older than any English tradition of storytelling, as Aboriginal civilization goes back at least 50,000 years (Kohen, 1995; Jupp, 2001). The history of David Gulpilil's life - from a young unknown non-English speaking actor, to his active role of inviting the director de Heer, providing the idea for making Ten Canoes and ending up being the film's narrator - parallels the history of Australian national cinema itself and its relation to Indigenous people. His biography is a reminder of the gradual, ongoing increase in Aboriginal participation and the shift from misrepresentation and romanticism to self-representation and partnership.

In his narration, Gulpilil begins with an explanation of the intrinsic connection between the creation of land, water and life as understood in Yolngu cosmology: 
This land began in the beginning. Yurlunggur, the Great Water Goanna, he travelled here. Yurlunggur made all this land then. He made this water... and he made this swamp that stretches long and gives us life... I come from a waterhole in this land Yurlunggur made... When I die, I will go back to my waterhole. I'll be waiting there, like a little fish...waiting to be born again...It's always like that for my people. (Gulpilil in Ten Canoes, 2006)

In the film's opening scene, Gulpilil presents Yurlunggur as the primary creator of Yolngu people in Arnhem Land. Yurlunggur can be related to the general theological figure of the Rainbow Serpent in Aboriginal cosmology (Leeming, 2006). However, the narrator explains that Yurlunggur is not a snake but a water goanna spirit. This differentiation draws attention to the common problematic generalisation of Aboriginal cosmologies. Anthropologist Sallie Anderson (2001, p. 296) argues that, involuntarily, anthropologists helped enforcing and spreading the erroneous conception of "the rainbow serpent as the pre-eminent creator figure" for all Aboriginal people in Australia.

In using the specific Yolngu name and avoiding a facile reference to mainstream/general understandings of Aboriginal culture, the narrator underlines that this story is for both audiences: Yolngu and non-Yolngu peoples simultaneously. Another example of the narrator's effort to educate is his description of the time of creation without referring to the English term of "Dreaming" or "Dreamtime". While generally adopted when referring to Aboriginal cosmology, this concept does not account to the complex diversity of Aboriginal concepts. Swain (1993) points out that the expression Dreamtime comes originally from a mistranslation of the term altjira used by the Arandas people in Central Australia. Missionaries appropriated the term as the closest one meaning to 'God'.
Anthropologists Francis James Gillen and Walter Baldwin Spencer were the first to translate Arandas' words into the term "the dream time" (Charlesworth, 1984). Differently, Strehlow interprets the meaning of the term altijira as closer to the "eternal, uncreated". He translated Altjira rama as the capacity of seeing the eternal, an act that is possible for someone as she/he sleeps and dreams. Strehlow (1971, p. 614) translated Altjiringa ngambakala as "having originated out of eternity, having originated out of one's own self" and Altijira rama as "I see eternal things" or "I see with eternal vision". By avoiding the term Dreaming, the narrator of Ten Canoes begins his story by stressing the perspective that will be present throughout the entire film: a narrative from the inside.

This presentation of a different world as viewed from inside, without the hierarchy of binary terms that colonial thought imposed on the continent and its peoples, is analogous to the concept of a pluriversal world put forward by Latin American thinker Walter Mignolo (2011, p. 176). For him, a pluriverse is "a world in which truth in parenthesis is accepted as universal". It does not mean a project of a universal world but the possibility of the existence of simultaneous but different worldviews. In the specific case of Indigenous people, this is compatible with Victoria Tauli-Corpuz's (2006, p. 13) claim that Indigenous people should have the right to remain separate and distinct from a mainstream model of development.

She stresses that this position should be welcomed by nations since Indigenous people are better prepared to preserve natural resources rather than destroy them for exclusively financial ends. The process of colonisation was not only about the imposition of power (through the implementation of economic and political systems) but also it was a process of subjugation of knowledge and being 
(Mignolo, 2011, p. 176). Therefore, the acceptance of a pluriversal world is the right to remain different without the connotation of inferiority.

Indeed, this is the case for the world as presented in Ten Canoes. The camera shows a bird's-eye view that scans the landscape of Arnhem Land, the flow of the blue river bounded by the green vegetation of eucalypts and corkscrew palms and grass suffused with the sounds of the wind, birds, insects and thunder that foreshadows an impending rain. Nature is presented as a living, moving force. The camera skims over the swamp establishing the importance of the environment for the understanding of the narrative and the motivation of the characters. In fact, the surrounding forests and swamps are also characters. The camera in movement animates them, framing land and waterscapes not as static but alive figures that are also part of the narrative.

After the astonishing image introducing spectators to the Ararufa swamp, the narrator Gulpilil declares, "the swamp gives us life". From these very first minutes, Ten Canoes invites viewers to see nature as a living force and being. The swamp is not a "biological commodity" that exists to be exploited for humans' convenience (Tauli-Corpuz, 2006, p. 15). As the film develops, anthropocentric views are challenged by the representation of the swamp as a key place of life, nourishment and death, inviting viewers to accept the understanding as advocated by Plumwood (2002) that humans and nature are intrinsically connected.

The film narrative depicts three different temporalities. The first one is the present time of the film wherein the storyteller Gulpilil informs viewers that he was a fish in the waterhole before being born. After dying, he will return to the same place to wait to be reborn. In the same way, he presents a second temporality of the film wherein Dayindi (Jamie Gulpilil), the younger brother, is being taught the Law through a story told by his older brother Minygululu (Peter Minygululu). This story is set in a third temporality, when Dayindi and Minygululu, as well as their ancestors, are still fishes in their waterholes waiting to be born. The story is set in a time after the beginning and following the big flood that covers the entire land. It is a time after the ceremony of Djungguwan that gave the Yolngu people their Law. The same Law, extant at the present time of the narrator, governed the ancient time. The story from ancient times is about Ridjimiraril (Crusoe Kurddal) and his three wives Nowalingu (Frances Djulibing), Banalandju (Sonia Djarrabalminym) and Munandjarra (Cassandra Malangarri Baker). His young brother Yeeralparil (Jamie Gulpilil) is interested in Munandjarra, the youngest wife. The story's moral lesson focuses on the importance of respecting the Law.

As the story unfolds, Ridjimiraril dies and his body is prepared for a journey. The family paints the design of his waterhole on him so that his spirit can find its way back to the same waterhole where he emerged. There he will wait to be born again, as previously explained by Gulpilil. The people sing and cry while painting his body. In this scene there is an intentional selective disclosure of Yolngu cultural information. The lack of explanations about the ceremony leaves the spectator unaware of the meaning of each act. By not elucidating religious procedures, the film director affirms his reluctance to provide detail. This is their ceremony.

The inquisitive viewer is not to be satisfied here. They are to be left wondering and this is deliberate. What is being conveyed is that something else is going on there but that something else is being withheld. This withholding of information makes the audience invited to remain as a distant observer. This is reinforced by the fact that the songs are deliberately not translated. As the film 
does not decode one of the most dramatic scenes, audience are not entitled to access all the ceremony meanings (Walker, 2015). The film deliberately and strategically eschews giving this explanation while simultaneously gesturing to the possibility that more could be said or understood.

As the film gets close to its end, each one of the narratives is carefully wrapped. The aerial shot of the swamp is interrupted by the camera diving very close to the water meaning that Ridjimiraril is back to his waterhole to wait to be born again in the cycle of continuous life. For Yeeralparil, following the Law, he assumes all three wives of his older brother. The narrator Gulpilil says that he does not know if Dayindi found or not a wife. In the film, this strategy reinforces the parallel between this temporality and ethnographic documentaries where, different from fictional narratives, many times is not possible to access information about the complete life of a character. And for the present time, Gulpilil concludes saying that, ".... Now you have seen my story. It is a good story. Not like your story, but a good story all the same". His words are followed by a strong laugh and the final credits are fulfilled by the ambient sound of the Arafura swamp. These sound that was present in the whole film reinforces the deep connection of the story with a particular and well-treated place.

The Indigenous characters of Ten Canoes are portrayed as those primarily responsible for nature's preservation and perpetuation. Val Plumwood argued in her Philosophical Animism theory for the importance of communication between species, stressing that humans need to develop the capacity to listen and to converse with other species. Animism introduces the possibility that the notions of humanity/personhood are not universal and that different sorts of subjects/beings may apprehend reality from distinct perspectives. The use here of a generic concept as Indigenous Animism is useful as it puts together a thread of common concerns that links indigenous cultures closer together than to mainstream societies against which they are often positioned.

The paradisiacal setting of Ten Canoes is rationalised by its chronological setting before colonisation; the non-Indigenous people are not present to spoil either the place or its inhabitants. However, by electing to set the story in the past, the film was criticised for giving "an emphasis on cultural loss", rather than showing the "dynamics of cultural change;" thus, conveying an impression that authentic Yolngu culture is essentially extinct (Riphagen \& Venbrux, 2008, p. 268). However, Ten Canoes in its sheer making, as an artefact, seems more committed to showing the relevance of traditional storytelling for cultural maintenance at a time of so many changes.

If it is possible to criticise Ten Canoes for presenting Indigenous life as static, repetitive and unchanging, a fundamental complement to it are all the audio-visual productions that followed the film and are available in the section of extras in the DVD format. One of them called People, Place and Ten Canoes displays several contemporary images otherwise absent from the film itself. A black screen with white titles introduces each film character with her/his proper Aboriginal name and sometimes their profession in life. The sequence is made exclusively with still photos and ambient sound (composed of different types of birds and insects, as well as the wind and water). The first photos are from the film, presenting the actors/actresses with their costumes/ make-up and using their everyday tools. The subsequent photos are from behind the scenes, showing their interaction with the camera, construction of the canoes and finally images from daily life activities such as grocery shopping, driving a motorcycle or 
posing for a family photo. These images embody a third temporality, the one initiated by David Gulpilil in his voice-over in the film. These images create a feeling of continuity from the older as well as mythical times presented by the narrator. This may explain why in this sequence of photos the ambient sound is replaced by Gulpilil's voice-over. He explains that his people are still living there in the swamp and sharing their lives but without the money required in the mainstream economy. He sings a song in his language, Mandalpingu, and then the ambient sounds of insects and birds return.

This sequence of photos and sounds seems to give an invitation to meet the Arafura Swamp people of today and to learn about their lives. Again, it is in the DVD's extra materials that contemporary life is presented as intrinsically connected with traditional practices such as the hunting of longneck turtles and fishing. At the same time, some vanished practices are presented even though they are far removed from contemporary daily life activities. For example, a traditional method of hand weaving a bag is depicted in which a woman reveals that she has seen the activity before but has never done it herself. Another impressive scene is of a young child who is invited to play with a breast-feeding clay doll, a copy based on one of the black-white photographs taken by anthropologist Donald Thomson, in the 1930s.

This sequence may be one of the reasons that the film Ten Canoes spawned an impressive number of follow-on projects. One of them is included on the same DVD as Ten Canoes, the project Eleven Canoes. It documents the teaching of audio-visual production; filming and editing that resulted in five short documentaries made by students of the Ramingining community. Twelve Canoes is a website project designed to talk about the culture and environment while Thirteen Canoes was an art exhibition of the artefacts created and used for the fictional feature. Fourteen Canoes is the name of the book displaying a combination of Donald Thomson's photos alongside stills from the film and from the people who acted there.

Other projects followed such as Fifteen $\mathrm{Ca}$ noes, centred on recording local songs; Sixteen Canoes, re-launch of the local television at the Ramingining community to screen the Eleven Canoes productions; Seventeen Canoes, a project where children that were part of the Eleven Canoes could share their learning with other remote communities; and finally, Eighteen Canoes is a project that resulted on The Balanda And The Bark Canoes (2006) (directed by de Heer, Reynolds and Nehme), a documentary about the challenges of making Ten Canoes. As a Balanda (white man), de Heer recalls dealing with many intercultural challenges to realise the film, such as communication. He observes that a clear point of distinction between both cultures is their language structure. He argues that whereas the English language is about classification and categorization, the Yolngu language is about connection and belonging to a unit. All these projects were motivated on the need of continuing the dialogue between the film and the community.

All these projects seem to answer possible criticisms of Ten Canoes. For example, its clear option to avoid discussion of and portrayal of the actual environmental challenges that Indigenous people are facing especially with their water resources in the Ararufa Swamp. In Ten Canoes, Indigenous people respect the natural cycles of the right season for hunting goose eggs, for example. There is no mention of contemporary threats such as the presence of feral animals, weeds, and fire as well as the intrusion of saltwater and rising sea level. In this sense, the film' aesthetics reinforces the belief that Indigenous people are in balance with 
nature thus leaving all threats outside of the screen. In this sense, the display of Indigenous ownership and management of territories is dissociated from the invasive colonial history.

In doing that, the film not only removes the colonial past but also the shaping forces of the present. In choosing to silence traumatic aspects of recent Australian history, the film offers a gaze of Aboriginal people living in better conditions. If the film lacks contextualisation, it concentrates in showing that the stories, the Law, are living things being enacted now at this time and place, being presented to fit two purposes: Yolngu purposes and the purpose of allowing the world to see aspects of their stories, their cosmologies and epistemologies.

\section{Conclusion}

Ten Canoes is not a film about cultures in transition but instead about continuity. It calls spectators to experience a contemporary encounter differently. Not immediately in their conflict zone but in the sharing of a story which nonetheless importantly stages difference. In the documentary The Balanda and the Bark Canoes, there are many statements by both de Heer and members of the Ramingining community involved in the making of the film that attest to their goals. For the Indigenous participants, these are framed in terms of achieving cultural preservation and respect. In this article, I claim to show the connection between cultural maintenance and respect to the natural environment. Although de Heer's stated goals do not touch on issues of environmental sustainability at all, I draw references from Ten Canoes in order to explore the themes of water and water conservation, based on the film narrative and form as well as on its circulation. The film serves as a source material for activism and campaigns because it provides a visual narrative of a nature and a way of life needing protection against predation.

Ten Canoes is not allegedly about how and why environmentalists and Indigenous groups sometimes agree on water rights battles. However, it is one of the most compelling feature films that seek to promote Aboriginal people connection with water in Australia. The film is not directly about environmental cultural challenges faced by Aboriginal people. Yet, it is inescapably caught up in it in terms of what it shows and claims. In this article, I point to the way this film touches on the relationship between economic and cultural water rights through its storytelling without this ever being a central topic. The film successfully presents the importance of water rights through an integrated perspective of Indigenous land and waterscapes.

\section{References}

Anderson, S. Rejecting the Rainbow Serpent: An Aboriginal Artist's Choice of the Christian God as Creator 1. Australian Journal of Anthropology, 12(3), 291-301, 2001.

Altman, J.; Jackson, S. Indigenous Land Management. In: Lindenmayer, S. et al. (Eds.). Commitments: Reshaping the Lucky Country's Environment., 2008. p. 207-214.
Berkes, F. Traditional ecological knowledge in perspective. In: Inglis, J. T. (Ed.). Traditional Ecological Knowledge: Concepts and Cases. Ottawa: International Program on Traditional Ecological Knowledge and International Development Research Centre. 1993. p. 1-9. 
Burdon, P. et al. Decolonising Indigenous water 'rights' in Australia: flow, difference, and the limits of law. Settler Colonial Studies, 5(4), 334-349, 2015.

Charlesworth, M. Introduction. In: Charlesworth, M. et al. (Eds.). Religion In Aboriginal Australia: An Anthology. University of Queensland Press; Lawrence, Mass., USA: Distributed in the USA and Canada by Technical Impex Corp, St. Lucia, Queensland, Australia, 1984.

Collins, F.; Davis, T. Australian cinema after Mabo. Cambridge University Press, 2004.

Davis, T. Remembering our Ancestors: Cross-Cultural Collaboration and the Mediation of Aboriginal Culture and History in Ten Canoes (Rolf de Heer, 2006). Studies in Australasian Cinema, 1(1), 5-14, 2007.

Eggerking, K. Landmarks: reading the Gove Peninsula. Australia, Camberra, Thesis (PhD) - Australia National University, 2014.

Gorman, J. et al. Population Estimate of Asian Water Buffalo and Wild Cattle in the Arafura Swamp, Central Arnhem Land. Northern Territory Naturalist, 19, 1-8, 2007.

Harvey, G. Animism: Respecting the Living World. London: Hurst. 2005.

Hunn, E. S. What is traditional Ecological Knowledge? In: Williams, N. M. et al. (Eds.). Traditional Ecological Knowledge: Wisdom for Sustainable Development. Canberra: Centre for Resource and Environmental Studies, Australian National University, 1993. p. 13-15.

Ingold, T. Rethinking the animate, re-animating thought. Ethnos, 71(1), p. 9-20, 2006.

Jackson, S.; Barber, M. Recognition of indigenous water values in Australia's Northern Territory: current progress and ongoing challenges for social justice in water planning. Planning Theory \& Practice, 14(4), p. 435-454, 2013.

Jupp, J. The Australian People: An Encyclopedia of the Nation, its People and their Origins. Melbourne: Cambridge University Press, 2001.

Kohen, J. L. Aboriginal Environmental Impacts. Sydney: University of New South Wales Press, 1995.

Lambert-Pennington, K. Thomson of Arnhem Land. Visual Anthropology Review, 17(1), 94-95, 2001.
Langton, M. Earth, wind, fire and water: the social and spiritual construction of water in Aboriginal societies. In: The Social Archaeology of Australian Indigenous Landscapes. Canberra: Aboriginal Studies Press, 2006. p. 139-160.

Leeming, D. Yurlunggur. In: The Oxford Companion to World Mythology. Oxford University Press, 2006.

Mala, G. An Indigenous Marine Protection Strategy for Manbuynga ga Rulyapa or the Arafura Sea. Prepared by the Ginytjirrang Mala with the assistance of A.D.V.Y.Z. for the Northern Land Council and Ocean Rescue 2000, Soft cover Darwin, 1994.

Mignolo, W. The Darker Side of Western Modernity: Global Futures, Decolonial Options. Durham: Duke University Press, 2011.

Morphy, H. Ancestral Connections: Art and an Aboriginal System of Knowledge. Chicago: University of Chicago, 1991.

Neale, T.; Turner, S. Other people's country: law, water, entitlement. Settler Colonial Studies, 5(4), 277-281, 2015.

Palace Films. Ten Canoes Press Kit. Sydney: Palace Films, 2006.

People, Place and Ten Canoes. Rolf de Heer and Peter Djigirr (Direção). Melbourne: Palace Films, 2006. DVD.

Plumwood, V. Environmental Culture: The Ecological Crisis of Reason. New York: Routledge, 2002.

Riphagen, M.; Venbrux, E. Ten Canoes. Visual Anthropology, 21(3), 266, 2008.

Rose, D. B. Indigenous Water Philosophy. In: Botterill, L. et al. (Eds.). From Disaster Response to Risk Management. Springer: Netherlands, 2005.

Rose, D. B. Val Plumwood's Philosophical Animism: Attentive Interactions in the Sentient World. Environmental Humanities, 3(1), 93-109, 2013.

Strehlow, T. G. H. In Historia Religionum. In: Bleecker, C. J. et al. (Eds.). Handbook for the history of religions. Volume II, Religious of the present. Leiden: E.J. Brill, 1971.

Swain, T. Worlds to endure. In: A Place for Strangers. Cambridge: Cambridge University Press. 1993. p. 13-68. Available from: Cambridge Books Online. Access Web 20 June 2016. 
The Tracker. 2002. Rolf de Heer (Director) Vertigo Productions, Asutralia, 2002. DVD

Toussaint, S.; Sullivan, P.; Yu, S. Water Ways in Aboriginal Australia: An Interconnected Analysis. Anthropological Forum, 15(1), 61-74, 2005.

Tylor, E. B. Primitive culture, vol. 1. New York: Harper and Row, 1958.

Tauli-Corpuz, V. Our Right to Remain Separate and Distinct. In: Mander, J. et al. (Eds.). Paradigm Wars: Indigenous Peoples' Resistance to Globalization. Los Angeles: Calif.: Sierra Club; Distributed by University of California, 2006.

Ten canoes. Rolf de Heer and Peter Djigirr (Direção). Melbourne: Palace Films, 2006. DVD.

The Balanda and the Bark Canoes. De Heer, Rolf, Molly Reynolds and Tania Nehme (Direção). Fandango, Film Australia, 2006. DVD
Wakulenko, I. Walkabout. In: International Dictionary of Film and Filmmakers. 2000. p. 1305-1307.

Walkabout. Nicholas Roeg (Directed). United States: Home Vision Entertainment, 1971. DVD.

Walker, E. Understanding sound tracks through film theory. Oxford: Oxford University Press, 2015.

Weston, N. et al. Arafura three: aboriginal ranger groups protecting and managing an internationally significant swamp. Ecological Management \& Restoration, 13(1), 84-88, 2012.

White, N. Meaning and metaphor in Yolngu landscapes, Arnhem Land, northern Australia. In: Trigger, D. S. et al. (Eds.). Disputed Territories: Land, Culture and Identity in Settler Societies. Hong Kong: Hong Kong University Press, 2003, p. 187-205. 